\title{
Introduction to the Special Issue on Mathematics Teacher Education Apparatuses
}

\author{
Caroline Lajoie • Frédérick Tempier
}

Published online: 5 June 2019

(C) Ontario Institute for Educat. Studies 2019

Within the francophone body of research in didactics of mathematics, the subject of teacher education has a history that varies from one region of the world to the other. Québec and France are a case in point. At the Université du Québec à Montréal (UQAM), for example, research projects in didactics of mathematics have been concerned with pre-service and in-service teacher education since the early 1970s (Bednarz, 2001, 2007). In France, it is in the early 1990s that "the teacher starts to become the research subject in various studies, while the didactician simultaneously becomes more involved in teacher education" (Margolinas \& Perrin-Glorian, 1997, p.10). It is also around this time that research studies on questions related to teacher education begin to emerge (take Houdement \& Kuzniak, 1996, for example). These distinct histories reveal a variety of approaches, questions, theoretical perspectives and methodologies used in studies conducted by francophone researchers to tackle the subject of teacher education.

In this special French-language issue, contributors hail from both sides of the Atlantic (Canada, Belgium and France). Our focus is on the study of mathematics teacher education apparatuses as they relate to the professional development of teachers. The term "apparatus" in this context includes mechanisms that vary in size and scale - from the "micro" level (requiring no more than a single session and which could be based on one or many tasks) to the "macro" level (deployed over a longer term and based on the organised implementation of a series of tasks carried out in sequence). The apparatuses under examination in this issue are implemented more or less in accordance with the "field" or with research in didactics of mathematics. They are applied to many user groups, from new teachers (in the context of theoretical courses or practicum) to more experienced teachers (continuing education), and amongst primary to secondary and even postsecondary teachers. In addition, depending on the tasks involved, the apparatuses may prompt student

\footnotetext{
${ }^{1}$ Translated from French: « que l'enseignant va commencer à devenir objet de recherche dans différents travaux, en même temps qu'augmente l'implication des didacticiens dans la formation des maîtres »

C. Lajoie $(\bowtie)$

Groupe de recherche sur la formation à l'enseignement des mathématiques [Research Group on Math Teacher Education] (GREFEM), Université du Québec à Montréal (UQAM), Montréal, Canada

e-mail: lajoie.caroline@uqam.ca

F. Tempier

Laboratoire de didactique André Revuz (EA 4434), UA, UCP, UPD, UPEC, URN, Université de Cergy-Pontoise,

Cergy-Pontoise, France

e-mail: frederick.tempier@u-cergy.fr
} 
teachers to adopt different epistemological stances, such as the perspective of the learner, the teacher or the university student (DeBlois \& Squalli, 2002).

Using teacher education apparatuses as an entry point, we can examine various aspects of teacher development, such as the types of knowledge that come into play-mathematical, didactic, pedagogical or professional - and their place within the framework. Examining teacher education apparatuses also gives us the opportunity to analyse the activities of both student teachers and teacher educators in relation to these different knowledge types.

Nevertheless, the study of teacher education apparatuses proves to be a complex task. This complexity could be due to the fact that the researchers are often involved in the process as teacher educators themselves, which makes the requisite detachment for conducting research projects more difficult. It also appears that the "density" of teacher education apparatuses complicates their analysis. The researchers merge and intertwine questions about teacher education with questions about the teaching and learning of mathematics - which is the crux of the teacher development process — ultimately updating and examining various "layers" or "levels" of analysis. The back-and-forth between these layers can be integrated into the apparatus or not, and whether it is can be indicative of how closely linked (or not) the apparatus is to the relevant teaching and learning issues. This is the point of departure used by COPIRELEM (Mangiante et al. 2019), for example, as well as by René de Cotret and Passaro (2018) in their study of teacher education apparatuses.

The origins of this special issue go back to a symposium held in Paris in July 2017. The symposium, entitled "Efficiency and adaptability of mathematics teacher education apparatuses for the professional development of future teachers" ${ }^{2}$ was part of the International Gatherings of the Research in Education and Professional Development Network ${ }^{3}$ (REF). At the event, participants, who prior to the conference had been divided into five teams (mostly composed of researchers from different countries), were invited to present an apparatus for teacher education and analyse it from various perspectives based on one or more of the following questions:

- What choices are driving the design of the apparatus? What aspects of mathematical, didactic or professional knowledge does the apparatus aim to address?

- What characteristics of the apparatus involve the use of mathematical, didactic or professional knowledge, and how does the apparatus create linkages between these types of knowledge?

- How does the apparatus take the needs, expertise and professional practices of teachers into account?

- What are the possible applications of the apparatus? How can it be adapted?

- What impact does the apparatus have on the professional development of teachers?

At the end of the symposium, three teams submitted an article for this special issue, and other researchers were invited to submit articles in order to cover a greater variety of approaches, frameworks, tools and perspectives. Our special issue starts out with articles that present more general options and then tips towards the study of teacher education apparatuses that are more time-bound. We have left the articles on apparatuses that involve the use of new technologies for the very end, which in a certain way delineates a path for moving forward.

In an article entitled, "Issues and modalities for the preparation of teachers in didactics of mathematics," 4 Pascale Masselot and Denis Butlen rely on research results on teacher education and teaching practices of school teachers in France (teaching ages 6 to 15). The authors use these findings to illustrate - in terms of issues and modalities - five major principles for the design and analysis of a holistic didactic development

\footnotetext{
${ }^{2}$ Translated from French: Efficience et adaptabilité de dispositifs de formation en mathématiques pour le développement professionnel des futurs enseignants

${ }^{3}$ Translated from French: Rencontres internationales du réseau de recherche en éducation et en formation (REF)

${ }^{4}$ Translated from French: Enjeux et modalités de formation pour les professeurs des écoles en didactique des mathématiques
} 
of school teachers: an approach that takes the complexity and coherence of practices into account. They also present four intervention techniques that teacher educators can use and describe the application of the five major principles using the experiences of various groups (pre-service teachers, new teachers and experienced teachers working in priority education) as examples.

In the article, "'Mathematics as a professional problem:' A particular aspect of reflexivity as the basis for an pre-service mathematics teacher education model," 5 authors Kevin Balhan, Isaline Gerard, Giang Nguyen Ngan and Maggy Schneider describe an approach developed as part of the pre-service mathematics teacher education at the University of Liège that is meant to foster the reflexivity of teachers who teach the final three years of secondary school in francophone Belgium (ages 15 to 18). Using the anthropological theory of the didactic, they show how mathematics, mathematical epistemology and didactics can be leveraged to meet this objective. To illustrate their proposition, the authors use mathematical analysis and geometry.

In "Learning to teach mathematics through problem-solving: A case study of the course Math Teaching II and $L a b$ at the Université du Québec à Montréal," ${ }^{6}$ Jérôme Proulx uses a narrative to present a teacher education initiative for future secondary-level math teachers in Quebec (ages 12 to 17). Throughout the description of the course, Proulx provides examples of accompanying problem-solving activities and presents the foundational principles that are meant to reveal the rationale of the educator/designer. These foundational principles highlight the parallels between the activities presented in the course for teaching through problem-solving and the activities deployed within the course that are used for the development of teachers.

In "Methodology for studying an interview between a teacher educator and a math student teacher conducted as part of a class visit," the class visit as an apparatus within the preservice secondary-level teacher education, focusing specifically on the interview that follows the observation of a math class led by the student teacher. The authors leverage the didactic-ergonomic double approach and the theory on the professional behaviour of teachers to develop a methodology for analysing the conduct of the interview and the "effects" the interview has on the capacity of the student teacher to develop a reflexive attitude. The authors then use this methodology to analyse the interview after observing a second-year statistics class in France (students age 15-16 years).

In the article, "Training to help a learner in mathematics: a study of the potentialities of a scenario based on role-play," ${ }^{8}$ Caroline Lajoie, Christine Mangiante, Pascale Masselot, Frédérick Tempier and Claire Winder Guille-Biel report on the "export" of an approach developed at the Université du Québec à Montréal-role-play - to pre-service elementary school teacher education in France (teaching ages 6 to 11). The scenario at the heart of the article is based on a role-play that immerses future teachers in a situation where they must help a pupil having difficulty with a task related to decimal numbers. The preliminary analysis of the scenario applies a theoretical model that illustrates the various levels of tasks involved. The article documents the knowledge and practices that emerged during the application of this scenario amongst two groups of pre-service elementary school teachers in France and illuminates the possibilities of the apparatus to help further develop the knowledge and practices of the teachers.

The apparatus analysed in the article "Computer simulators as a resource for math teacher education" 9 is a computer simulator for math teaching practices. Fabien Emprin and Hussein Sabra define three general criteria to consider when designing this kind of simulator. They base their work, first, on the benefits and

\footnotetext{
${ }^{5}$ Translated from French: Une dimension particulière de la réflexivité : « les mathématiques comme problème professionnel »à la base d'un dispositif de formation initiale en didactique des mathématiques

${ }^{6}$ Translated from French: Faire vivre une formation à l'enseignement des mathématiques par résolution de problèmes : le cas du cours " Didactique des mathématiques II et Laboratoire » à l'Université du Québec à Montréal

${ }^{7}$ Translated from French: Méthodologie pour l'étude didactique d'un entretien formateur/professeur stagiaire en mathématiques dans le cadre d'une visite de classe

${ }^{8}$ Translated from French: Former à aider un élève en mathématiques : une étude des potentialités d'un scénario de formation basé sur un jeu de rôles

${ }^{9}$ Translated from French: Les simulateurs informatiques, ressources pour la formation des enseignants de mathématiques
} 
risks of introducing digital technologies into teacher education, and second, on two theoretical frameworks that help define, understand and analyse technology-based teaching practices: the didactic-ergonomic double approach and the instrumental approach. The authors then show how they took the criteria into account in the development of a simulator that immerses the user in a class where students have to solve an open problem in geometry with the help of dynamic geometry software.

In the last article of this special issue, "MERLO task development: A model used in continuing education for teaching geometry," 10 Mathieu Thibault and Nathalie Sinclair present the results of an exploratory study involving the development of MERLO tasks by secondary school teachers (ages 12 to 18) enrolled in a continuing education programme at Simon Fraser University (British Columbia, Canada). In this study, the development of MERLO tasks is intended to help teachers deconstruct secondary-level geometry concepts. Using examples of tasks developed by the teachers, the authors identify important issues that the apparatus brings to light, particularly with regard to how the registers of visual and linguistic representation intersect. The incorporation of dynamic figures into the creation of tasks leads the authors to propose an expansion of Raymond Duval's theory by including a new register of representation: the dynamic register.

We hope that this special issue will initiate deeper reflection, supported by research, about mathematics teacher education apparatuses, and that it will prompt other researchers in Canada and elsewhere in the world to contribute to this area of thought.

\section{References}

Bednarz, N. (2001). Didactique des mathématiques et formation des enseignants: le cas de l’Université du Québec à Montréal. Revue canadienne d'enseignement des mathématiques, sciences et technologies, 1(1), 61-80.

Bednarz, N. (2007). Ancrage de la didactique des mathématiques au Québec: à la recherche de sens et de cohérence. In Actes du colloque du Groupe de Didactique des Mathématiques au Québec (pp. 21-61).

DeBlois, L. and Squalli, H. (2002). Implication de l'analyse de productions d'élèves dans la formation des maîtres du primaire. Educational Studies in Mathematics, 50(2), 212-237.

Houdement, C. and Kuzniak, A. (1996). Autour des stratégies utilisées pour former les maitres du premier degré en mathématiques. Recherches en didactique des mathématiques, 16(3), 289-322.

Mangiante, C., Masselot, P., Petitfour, E., Simard, A., Tempier, F., Winder, C. (2019). Pratiques de formation en mathématiques des professeurs des écoles : un cadre pour analyser les potentialités de situations de formation. In I. Verscheure, M. Ducrey-Monnier, and L. Pelissier (dir.), Enseignement et formation : éclairages de la didactique comparée. Toulouse, France : Presses Universitaires du Midi.

Margolinas, C. and Perrin-Glorian, M.-J. (1997). Des recherches visant à modéliser le rôle de l'enseignant (éditorial du volume 17/3). Recherches en Didactique des Mathématiques, 17/3, 7-16.

René de Cotret, S. and Passaro, V. (2018). « J'avais jamais vu ça comme ça avant !» Un projet de recherche-action collaborative pour la formation continue en mathématiques au secondaire. In J.-L. Dorier and S. Coutat (dir.) Actes du colloque Espace Mathématique Francophone EMF 2018 (SPE4, pp. 20-21).

Publisher's Note Springer Nature remains neutral with regard to jurisdictional claims in published maps and institutional affiliations.

\footnotetext{
${ }^{10}$ Translated from French: Conception de tâches MERLO : un dispositif dans la formation continue pour l'enseignement de la géométrie 